\title{
Hydrological Modelling of Catchments at Industrial Sector
}

\author{
M. Satish Kumar, Ambati Dattatreya Kumar, Hepsibah Palivela, M. V. Raju, T. Ch. Anil Kumar
}

\begin{abstract}
In any nation industries are the major sources for the country economy and also the major source of employment for the people of any nation. Industries are also considered as prime reason for the developmental activities with huge employment potential at the other side the environmental conditions in and around the industries are degrading very rapidly due to the lack of proper supervision on disposal of industrial wastes along with the emissions releasing into the open atmosphere by few of the industries [9] without any concern of human health eventually over a period of time all the effluents and the emissions released into the open atmosphere without treatment shows dangerous consequences on the environment in the society. The major requirements of any industries starts with water only, as the water is prime element for the survival any living organism on the earth and also the water is the prime component for the development of any area but at certain areas the water both surface and ground water [11] sources have been contaminating due to the unethical and unscientific disposal of wastes into the open lands as well as into the nearby water bodies. when we emphasize the reason behind this specific activity we came to understand that improper maintenance of effluent treatment plants and the effluents releasing from them shows its severe impacts on nearby aquatic organisms [3], if the same water is used for domestic activities there will be a damage for human health and sometimes it may leads to the death of the individuals also. In the present study three locations were indentified around the boundaries [8] of catchment based on the entry of flow into the catchments and the samples were collected for three times in the study period of three months, all the samples were marked with labels and analysis [2] was carried out by using prescribed analytical procedures, the results were compared with surface water quality standards [1] specified by Central Pollution Control Board,1979 and the Bureau of Indian standards, 1982 to find out the hydrology of the catchment
\end{abstract}

Keywords: Catchments, Effluent, Environment, Hydrology, Industries, Treatment.

\section{INTRODUCTION}

Catchments are the water bodies where the water enters into it either by runoff or through rain fall depends on the existed geological conditions and topography of the soil along with climatic conditions prevailed over a period of time.

Revised Manuscript Received on February 05, 2020.

* Correspondence Author

Dr. M. Satish Kumar*, Professor, Department of Civil Engineering, Kallam HarandhaReddy Institute of Technology, Guntur, A.P., India.

Ambati Dattatreya Kumar, Assistant Professor in Department of Civil Engineering, V.R Siddhartha Engineering College, Vijayawada, A.P., India. Dr. Hepsibah Palivela, UGC- Post Doctoral Fellow, Centre for Women Studies, Andhra University, Visakhapatnam, A.P., India.

M. V. Raju, Assistant Professor, Department of Civil Engineering, Vignans Foundation for Science Technology and Research, A.P., India.

T. Ch. Anil Kumar, Assistant Professor, Department of Mechanical Engineering, Vignans Foundation for Science Technology and Research, Guntur, A.P., India.

(c) The Authors. Published by Blue Eyes Intelligence Engineering and Sciences Publication (BEIESP). This is an open access article under the CC BY-NC-ND license (http://creativecommons.org/licenses/by-nc-nd/4.0/)
Normally catchments are the major source of water for irrigation and domestic activities when they are situated in any area or near by the fields but if they situated nearby industrial sectors mostly they serves as source of effluent discharge, where more concentration is needed with respect to the aquatic ecosystem and also for the public health.

Sometimes the effluents releasing into the water bodies without treatment may show their long term consequences on environment [6] when they infiltrate into the ground which in turn leads to groundwater contamination, before the problem turns into more complex there should be a proper long term and short term policies to rejuvenate the ecosystem of the catchment by making strict implementation of industrial acts where the zero discharge policy's are set for effluents before they are releasing into the nearby catchments[12]. The present study was carried out at the catchment in the industrial sector of Guntur Municipal Corporation. The study was carried out within the duration period of three months where the samples were collected for three times, all the samples were collected by using a sterilized glass bottle at three corners of the catchment and then labelled with the description of sampling locations with date of collection. Standard analytical methods were employed to identify the concentration [8] of various parameters. Results were correlated with surface water quality standards specified by Central Pollution Control Board, 1979 and the Bureau of Indian standards, 1982 to get the category of the catchment with respect to the effluents concentration.

\section{OBJECTIVES}

1. Identification of sampling locations to collect the samples from the catchment

2. Adoption of suitable methodology to conduct the test for parameters.

3. Correlation of the results with Central Pollution Control Board, 1979 and the Bureau of Indian standards, 1982

4. Preparation of guidelines to rejuvenate water quality of the catchment

\section{METHODOLOGY}

\section{III.I Sampling Points:}

1. Total three sampling locations were identified after collecting the data of possible ways of water entry into the catchments through runoff or by the discharges of nearby industries

2. Samples were collected for three times in the period of three month study period

3. All the samples were collected in a clean sterilized glass bottles

4. All the collected sample bottles were labelled and then sent for analysis. 


\section{Hydrological Modelling of Catchments at Industrial Sector}

III.II Water quality Analysis:

1. The analysis was carried out for the parameters like $\mathrm{P}^{\mathrm{H}}$, Electrical Conductivity, Alkalinity, Total Hardness, Turbidity, Total Solids (TS), Total Dissolved Solids (TDS), Total Suspended Solids, Dissolved Oxygen (DO), Chlorides and Biological Oxygen Demand (BOD) to find out the existed condition of the catchment.

2. By employing standard chemical analysis [5] procedures the entire above mentioned tests were conducted.

3. Three samples were collected from the identified points around the catchment

Table 1: Catchment water quality I cycle

\begin{tabular}{|c|c|c|c|c|}
\hline \multirow{2}{*}{ S.NO } & \multirow{2}{*}{ PARAMETER } & \multicolumn{3}{|c|}{ Month I } \\
\hline & & Location 1 & Location 2 & Location 3 \\
\hline 1 & $\mathrm{P}^{\mathrm{H}}$ & 7.9 & 8 & 8.14 \\
\hline 2 & Electrical Conductivity & 3800 & 3350 & 3850 \\
\hline 3 & Alkalinity & 500 & 485 & 470 \\
\hline 4 & Total Hardness & 910 & 920 & 910 \\
\hline 5 & Turbidity & 44 & 38 & 45 \\
\hline 6 & Total Solids & 3640 & 3380 & 3830 \\
\hline 7 & Total Dissolved Solids & 3040 & 2680 & 3080 \\
\hline 8 & Total Suspended Solids & 600 & 700 & 750 \\
\hline 9 & Dissolved Oxygen & 3 & 1.5 & 2.8 \\
\hline 10 & Chlorides & 640 & 730 & 725 \\
\hline 11 & Biochemical Oxygen Demand & 2.5 & 110 & 150 \\
\hline
\end{tabular}

All the units are in mg/l except pH, Turbidity (NTU) and EC ( $\mu$ mhos/cm)

Table 2: Catchment water quality II cycle

\begin{tabular}{|c|c|c|c|c|}
\hline \multirow[b]{2}{*}{ S.NO } & \multirow{2}{*}{ PARAMETER } & \multicolumn{3}{|c|}{ Month II } \\
\hline & & Location 1 & Location 2 & Location 3 \\
\hline 1 & $\mathrm{P}^{\mathrm{H}}$ & 7.25 & 8 & 7.4 \\
\hline 2 & Electrical Conductivity & 3850 & 3830 & 3500 \\
\hline 3 & Alkalinity & 540 & 530 & 535 \\
\hline 4 & Total Hardness & 950 & 980 & 700 \\
\hline 5 & Turbidity & 44 & 45 & 48 \\
\hline 6 & Total Solids & 3820 & 3784 & 3480 \\
\hline
\end{tabular}

Analysis was done for three times for three months for all the three samples by Central Pollution Control Board, 1979 and the Bureau of Indian standards, 1982. 


\begin{tabular}{|c|l|c|c|c|}
\hline 7 & Total Dissolved Solids & 3080 & 3064 & 2800 \\
\hline 8 & Total Suspended Solids & 740 & 720 & 680 \\
\hline 9 & Dissolved Oxygen & 2.4 & 3.4 & 650 \\
\hline 10 & Chlorides & 630 & 600 & 300 \\
\hline 11 & Biochemical Oxygen Demand & 2 & 365 & 3 \\
\hline
\end{tabular}

All the units are in mg/l except pH, Turbidity (NTU) and EC ( $\mu$ mhos/cm)

Table 3: Catchment water quality III cycle

\begin{tabular}{|c|l|c|c|c|}
\hline \multirow{2}{*}{ S.NO } & \multicolumn{1}{|c|}{ PARAMETER } & \multicolumn{2}{c|}{ Month III } \\
\cline { 3 - 5 } & & Location 1 & Location 2 & Location 3 \\
\hline 1 & $\mathrm{P}$ & 7.4 & 8 & 7.6 \\
\hline 2 & Electrical Conductivity & 3550 & 3455 & 3650 \\
\hline 3 & Alkalinity & 550 & 480 & 520 \\
\hline 4 & Total Hardness & 930 & 850 & 400 \\
\hline 5 & Turbidity & 48 & 49 & 3610 \\
\hline 6 & Total Solids & 3500 & 3404 & 2920 \\
\hline 7 & Total Dissolved Solids & 2840 & 2964 & 690 \\
\hline 11 & Biochemical Oxygen Demand & 660 & 640 & 3.5 \\
\hline 9 & Dissolved Oxygen & 2.8 & 2.7 & 650 \\
\hline
\end{tabular}

All the units are in mg/l except pH, Turbidity (NTU) and EC ( $\mu$ mhos/cm)

\section{RESULTSAND DISCUSSIONS}

\begin{tabular}{|c|l|l|}
\hline S.NO & \multicolumn{1}{|c|}{ PARAMETER } & \multicolumn{1}{c|}{ EXPLANATION } \\
\hline 1 & $\mathrm{P}^{\mathrm{H}}$ & $\begin{array}{l}\text { The } \mathrm{P}^{\mathrm{H}} \text { of the catchment is within the acceptable limits throughout the study period as } \\
\text { per the surface water quality standards by Central Pollution Control Board, 1979 and } \\
\text { the Bureau of Indian standards, 1982. }\end{array}$ \\
\hline 2 & $\begin{array}{l}\text { Electrical } \\
\text { Conductivity }\end{array}$ & $\begin{array}{l}\text { When the Electrical conductivity is compared with surface water quality standards by } \\
\text { Central Pollution Control Board, 1979 and the Bureau of Indian standards, 1982 it is } \\
\text { with is crossed the permissible limits. }\end{array}$ \\
\hline 5 & $\begin{array}{l}\text { Biochemical Oxygen } \\
\text { Demand }\end{array}$ & $\begin{array}{l}\text { The Biochemical Oxygen Demand of the catchment shows the characteristics of 'B' } \\
\text { Outdoor bathing (organized) type water body as per the surface water quality standards } \\
\text { by Central Pollution Control Board, 1979 and the Bureau of Indian standards, 1982 it is } \\
\text { with is crossed the permissible limits. }\end{array}$ \\
\hline 6 & $\begin{array}{l}\text { The turbidity level of the catchment is high and it is not acceptable proper treatment is } \\
\text { highly required. }\end{array}$ \\
\hline & $\begin{array}{l}\text { In the present study very low dissolved oxygen is noted when it is compared with } \\
\text { surface water quality standards by Central Pollution Control Board, 1979 and the } \\
\text { Bureau of Indian standards, 1982 it is with is crossed the permissible limits indicates } \\
\text { excessive algal growth in the catchment. }\end{array}$ \\
\hline
\end{tabular}




\begin{tabular}{|c|l|l|}
\hline 7 & Total Dissolved Solids & $\begin{array}{l}\text { The concentration of total solids is high when correlated with surface water quality } \\
\text { standards by Central Pollution Control Board, 1979 and the Bureau of Indian } \\
\text { standards, 1982 it is with is crossed the permissible limits. }\end{array}$ \\
\hline 8 & Chlorides & $\begin{array}{l}\text { The concentration of chlorides is very high when it is compared with surface water } \\
\text { quality standards by Central Pollution Control Board, 1979 and the Bureau of Indian } \\
\text { standards, 1982 it is with is crossed the permissible limits. }\end{array}$ \\
\hline 9 & $\begin{array}{l}\text { 1. The water quality in the catchment is highly contaminated the concentration of other parameters like hardness, } \\
\text { total solids, total suspended solids also not in the limits required high level treatment is required } \\
\text { 2. The effluents from the industries must be monitored and should be zero discharge with respect to chemicals } \\
\text { releasing into the catchments. }\end{array}$ \\
\hline
\end{tabular}

\section{CONCLUSIONS}

1. The hydrology of catchment is always dynamic as it is depending on the existed geological parameters along with effluents or runoff entering into the catchment.

2. The effluents [4] discharge from the nearby industries should be monitored regularly

3. Industries must follow the guiltiness of surface water quality standards by Central Pollution Control Board, 1979 and the Bureau of Indian standards, 1982

4. The catchments must be monitored periodically with respect to its water quality and the sanitary measures around the catchments.

5. The effluent treatment plants [10] must be designed as per the requirements with advanced technological innovations to reduce the intensity of the hazardousness of the waste water before it is releasing into the catchments.

6. Common effluent treatment plants must be encouraged if the industries are unable to maintain individual effluent treatment plants.

7. The staff quarters must be constructed in the industry itself to look after the discharge of effluents releasing into the nearby water bodies and proper precautions must be given to them in such a way to release the effluents with Zero chemical percentage.

\section{REFERENCES}

1. Surface water quality criteria for different uses (specified by СРСВ, 1979 and the Bureau of Indian Standards, 1982)

2. Chemical Analysis of Water and Soil, Third Edition, by Dr. KVSG Murali Krishna.

3. Remediation of urban lake water and sediments" by M. Satish Kumar, Ambati Dattatreya Kumar, P. Srinivasa Rao, G. Venu Ratna Kumari published in International Journal of Recent Technology and Engineering, Volume No: 8. Issue No: 5, January 2020, pp 2338 - 2341, ISSN: 2277-3878.

4. Manivasakam.N., Physico chemical Examination of Water, Sewage and Industrial Effluents, Pragati Prakasham,p.234(2202)

5. Interpretation and correlative study of water simulation in surface water bodies: , by M.Satish Kumar, M.V Raju, S.Ramesh babu and M.saiva jagadesh kumar published in International Journal of Civil Engineering and Technology, Volume No: 8. Issue No:5, May 2017, pp 1206 - 1211, ISSN: 0976-6308.

6. Y. Anjaneyulu, Introduction to Environmental Science, Edition, B.S Publications, Hyderabad, 2004.

7. Water quality scenario in urban polluted lakes : A model study by M.Satish Kumar ,M.V Raju, Hepsiba palivela and G.Venu Ratna kumari published in International Journal of Civil Engineering and Technology, Volume No: 8. Issue No: 5, May 2017 pp 297 to 302., ISSN:0976-6316.

8. Brindha, k., \& Elango,L.(2013),Environmental assessment of water quality in nagarjuna sagar reservoir, India. earth Resourses,1(1),PP.33-36,https:/doi.org/10.12966/er05.05.2013.

9. Quality Characteristics of Ground Waters in Few Sources of Industrial Zone " by Hepsibah Palivela, B. Ravali, M.V.Raju, K.Maria Das, T.Ch.Anil Kumar , International Journal of Innovative Technology and Exploring Engineering, Volume No: 9. Issue No: 3, January 2020, pp $1134-1137$

10. Text book on Environmental Engineering-I: Principles of water supply engineering by Satish Kumar Moparhi published by Lambert academic publishing with ISBN 978-613-7-45184-7.

11. Comprehensive index of groundwater prospects by using standard protocols - A model study, M.Satish Kumar M.V Raju., and Hepsiba palivela in International Journal of Civil Engineering and Technology, Volume No: 8. Issue No: 05, 2017 pp 521 - 526. ISSN: 0976-6316.

12. Anjaneyulu $Y$, Water resources pollution, Water quality management and monitoring, Proceedings of International conference on hydrology and water shed management Vol-II, 554-561.

\section{AUTHORSPROFILE}

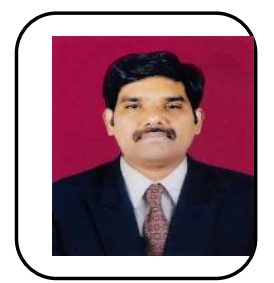

Dr. Satish Kumar Moparthi, is the professor of Civil Engineering in Kallam HarandhaReddy Institute of Technology, Guntur, Andhra Pradesh, India. He has published two text books and he has more than 35 International journals in the field of Civil Engineering. He got sanctioned grant from Science and Engineering Research Board, Department of Science and Technology, Government of India.

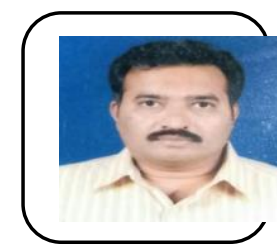

Mr. Ambati Dattatreya Kumar, is the Assistan Professor in department of Civil Engineering, V.R Siddhartha Engineering College, Vijayawada, Andhra Pradesh, India. He has 10 Years of teaching experience along with 15 years of Industrial experience in the field of Civil Engineering.

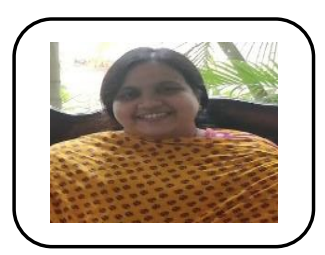

Dr. Hepsibah Palivela, is the UGC Post Doctoral fellow, Centre for Women Studies, Andhra University. Visakhapatnam, A.P.India. She has published more than 20 Research Publications indexed in various SCI/Scopus Cited Journals

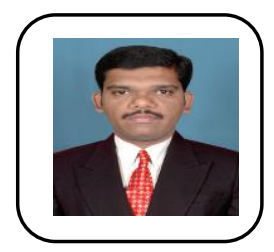

Mr. M. V. Raju, M.Tech from JNT University, Kukatpaaly, Hyderabad, and presently as Assistant Professor, Department of Civi Engineering, VFSTR, Deemed to be University, Vadlamudi, Guntur, A.P., India .

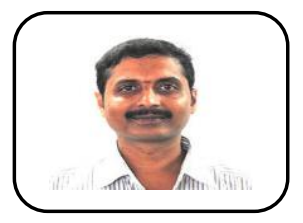

Mr. T. Ch. Anil Kumar, is the Assistan Professor, Dept. of ME, VFSTR, Deemed to be University, Guntur, A.P., India and he has 14 years of Teaching and Research experience, published more than 14 Research articles in Elsevier and other Scopus Indexed Cited Journals 